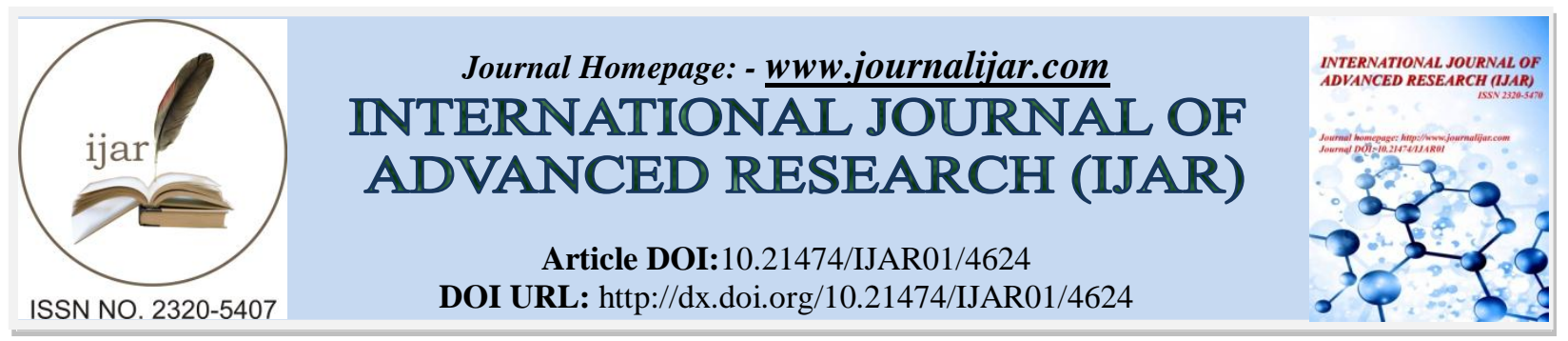

RESEARCH ARTICLE

\title{
CHEMICAL COMPOSITION AND ANTI-INFLAMMATORY ACTIVITY OF APIGENIN - 7- 0 - (6" - 0 - CAFFEOYL) - $\beta$-D- GLUCOPYRANOSIDE EXTRACTED FROM CISSUS QUADRANGULARIS.
}

*Vijayaraj Chellaiyan and Senguttuvan Swaminathan.

Department of Chemistry, Thiru.Vi.Ka. Government Arts College, Thiruvarur, Tamilnadu, India-610 003.

\section{Manuscript Info}

\section{Manuscript History}

Received: 26 April 2017

Final Accepted: 28 May 2017

Published: June 2017

Key words:-

Anti-inflammation, Apigenin, Caffeic acid, Cissus quadrangularis, Vitaceae

\section{Abstract}

Cissus quadrangularis L. is a delicious plant of family Vitaceae commonly found in tropical and subtropical xeric wood. Flavonoids are one of secondary metabolites produced by plants. Flavonoids and phenolic acids have protective part in carcinogenesis, inflammation, atherosclerosis, thrombosis and have high anti-oxidant capacity. Inflammation is a part of the immune response against infection and has been associated in a broad range of diseases like as including diabetes, cancer, hypertension and atherosclerosis. The aim of the present study is to investigate the pharmacognostical and phytochemical investigation of the flower parts of the plant Cissus quadrangularis. Moreover, the absence of toxicity of plant extracts and the isolation of active compounds are significant to propose these plants as alternative approaches to resistance management and important inhibitory effect on the oedema formation. The structure was established based on analysis of HPLC, UV, IR, ${ }^{1} \mathrm{H}$ NMR and ${ }^{13} \mathrm{C}$ NMR spectroscopy methods.

Copy Right, IJAR, 2017,. All rights reserved.

\section{Introduction:-}

Flavonoids are one of secondary metabolites produced by plants (Harborne et.al.1994). They play many vital roles such as pigmentation, pathogen resistance, UV light protection, growth and development in plants (Vvedenskaya et.al.2004). From a human point of view, flavonoids can afford protection against many diseases because of their anti-oxidant activities. Flavonoids and phenolic acids have protective part in carcinogenesis, inflammation, atherosclerosis, thrombosis and have high anti-oxidant capacity. Many other biological activities are ascribed to flavonoids and phenolic acids: anti-viral, anti-microbial, anti-hepatotoxic, anti-ulcer, anti-proliferative and apoptotic activity (Fairouz et.al.2010). Furthermore, flavonoids have been reported as aldose reductase inhibitors blocking the sorbitol pathway that is linked to many problems accompanying with diabetes (Harborne et.al.2000).

Inflammation is a part of the immune response against infection and has been associated in a broad range of diseases like as including diabetes, cancer, hypertension and atherosclerosis (Schmid et.al.2006). It is the body's immediate response to injury its tissues and cells by pathogens or physical injury (Duncan et.al.2003).These instigators induce activation of inflammatory mediators such as kinins, cyclo-oxygenase products and cytokines, which have become key targets for therapeutic interposition in a range of diseases including pain (Weiss 2008).

Cissus quadrangularis L. is a delicious plant of family Vitaceae commonly found in tropical and subtropical xeric wood (Anonymous, 1992). It is a fleshy, cactus-like climber widely used as a common food item in India. The plant 
is prescribed in the ancient ayurvedic literature as a general tonic and analgesic, with specific bone fracture healing properties (Guhabakshi, 2001). The scrutiny of literature revealed some notable pharmacological activities of the plant such as anti-oxidant, free radical scavenging, anti-microbial, anti-bacterial, bone healing, anti-ulcer, analgesic and diuretic, presented in this review such that the potential use of the plant either in pharmaceutics resource can be evaluated. The juice of stem is useful in scurvy and in irregular menstruation whereas the stem paste boiled in lime water is given in asthma. It is also used as a powerful stomachic (Jainu et.al.2003). The aim of the present study is to investigate the pharmacognostical and phytochemical investigation of the flower parts of the plant Cissus quadrangularis.

\section{Materials and Methods:- Collection of plant material:-}

The fresh flowers of Cissus quadrangularis were collected in the month of December - January from the area of Cauvery river basin, Thiruvarur, Tamilnadu, India. These Plants were identified and authentic by Dr. S. Soosairaj, Assistant Professor, Department of Botany, St.Joseph's College (Autonomous), Bharathidasan University, Trichirappalli, Tamilnadu, India. The voucher specimen (SJCBOT2281) was preserved in our research laboratory for future reference. The plant material was air dried, smashed into powder and stored in a dessicator for further use.

\section{Isolation and Identification:-}

The significant stage in the experimental work embraces first the isolation of chemical substances from the chosen plant and secondly, the characterization of those isolated compounds. The flowers of Cissus quadrangularis (2.5 $\mathrm{Kg}$ ) were extracted with $90 \%$ methanol $(\mathrm{MeOH})(5 \mathrm{X} 500 \mathrm{ml})$ under reflux. The alcoholic extract was concentrated in vacuo and the aqueous concentrate was fractionated with peroxide free ether $(4 \times 250 \mathrm{ml})$ and ethyl acetate $(8 \mathrm{x}$ $250 \mathrm{ml}$ ) (Sigma Aldrich Co., India).

The residue from ethyl acetate segment was taken up in acetone and left in an ice-chest for two days when a yellow solid separated. It prominent a greenish brown colour with alc. $\mathrm{Fe}^{3+}$, formed yellow precipitate with basic lead acetate solution and reduced ammoniacal $\mathrm{AgNO}_{3}$ but not Fehling's solution. It contributed yellow colour with aqueous $\mathrm{NaOH}$ intense yellow with Con. $\mathrm{H}_{2} \mathrm{SO}_{4}$ and magenta colour with $\mathrm{Mg} / \mathrm{HCl}$. It appeared deep purple under UV which turned yellow and disclosure to $\mathrm{NH}_{3}$. It retorted to Wilson's Boric Acid, Gibbs and Molisch's tests but not answer to Horhammer- Hansel tests.

Supporting objective for the structure of the flavone glycoside is provided by the HPLC (Shimadzu, Columbia), UV (Perkin Elmer Spectrophotometer), IR (Perkin - Elmer spectrometer) and NMR (125 MHz and $500 \mathrm{MHz}, \mathrm{CDCl}_{3}$ ) spectral data were recorded on a Bruker AMX NMR spectrometer. Chemical shifts were reference to the equivalent residual solvent peaks and the values were recorded in $\delta$.

\section{Apigenin -7- $O$ - ( $6^{\prime \prime}-O$ - caffeoyl $)$ - $\beta$ - D - glucopyranoside}

Yellow amorphous powder; m.p. 240-242 C; RT $26.4 \mathrm{~min}$; UV $\lambda_{\max }^{\mathrm{MeOH}}$ (log ع) $272-319 \mathrm{~nm}$; IR (KBr): $v_{\max } 3312$, 2990, 2949, 2838, 1646, 1559, 1537, 1448, 1405, 1205, 1158, 1102, 1078 and $1013 \mathrm{~cm}^{-1} ;{ }^{1} \mathrm{H}\left(500 \mathrm{MHz}, \mathrm{CDCl}_{3}\right) \delta$ ppm: 8.83 (H-3), 7.92 (H-6), 7.91 (H-8), $7.66\left(\mathrm{H}-2^{\prime}\right), 7.65\left(\mathrm{H}-6^{\prime}\right), 7.63\left(\mathrm{H}-3^{\prime}\right), 7.43\left(\mathrm{H}-5^{\prime}\right), 5.13\left(\mathrm{H}-1^{\prime \prime}\right), 3.66\left(\mathrm{H}-2^{\prime \prime}\right)$, 3.47 (H-3"'), $3.36\left(\mathrm{H}-4^{\prime \prime}\right), 3.82\left(\mathrm{H}-5^{\prime \prime}\right), 4.07$ (H-6"'), $7.26\left(\mathrm{H}-1^{\prime \prime \prime}\right), 7.43\left(\mathrm{H}-5^{\prime \prime \prime}\right), 7.42\left(\mathrm{H}-6^{\prime \prime \prime}\right), 7.29\left(\mathrm{H}-7^{\prime \prime \prime}\right), 7.28(\mathrm{H}-$ $\left.8^{\prime \prime \prime}\right), 12.40(5-\mathrm{OH}) ;{ }^{13} \mathrm{C}-\mathrm{NMR}\left(125 \mathrm{MHz}, \mathrm{CDCl}_{3}\right) \delta \mathrm{ppm}: 154.1$ (C-2), 124.4 (C-3), 198.4 (C-4), 162.7 (C-5), 151.8 (C-6), 147.3 (C-7), 138.8 (C-8), 136.2 (C-9), 130.7 (C-10), 129.9 (C-1'), 129.6 (C-2'),129.59 (C-3'), 129.53 (C-4'), $129.02\left(\mathrm{C}-5^{\prime}\right), 128.96\left(\mathrm{C}-6^{\prime}\right), 105.9\left(\mathrm{C}-1^{\prime \prime}\right), 77.3\left(\mathrm{C}-2^{\prime \prime}\right), 76.7\left(\mathrm{C}-3^{\prime \prime}\right), 72.6\left(\mathrm{C}-4^{\prime \prime}\right), 61.8\left(\mathrm{C}-5^{\prime \prime}\right), 53.7\left(\mathrm{C}-6^{\prime \prime}\right), 128.5$ $\left(\mathrm{C}-1^{\prime \prime \prime}\right), 128.3\left(\mathrm{C}-2^{\prime \prime \prime}\right), 128.1\left(\mathrm{C}-3^{\prime \prime \prime}\right), 126.6\left(\mathrm{C}-4^{\prime \prime \prime}\right), 124.4\left(\mathrm{C}-5^{\prime \prime \prime}\right), 147.3\left(\mathrm{C}-6^{\prime \prime \prime}\right), 116.8\left(\mathrm{C}-7^{\prime \prime \prime}\right), 112.5\left(\mathrm{C}-8^{\prime \prime \prime}\right)$, $176.1\left(\mathrm{C}-9^{\prime \prime \prime}\right)$.

\section{Hydrolysis of the glycoside:-}

The glycoside liquefied in hot aqueous methanol was hydrolyzed with $\mathrm{H}_{2} \mathrm{SO}_{4}(5 \%)$ at $100^{\circ} \mathrm{C}$ for around 2 hrs. The excess of alcohol was distilled off in vacuo and the consequent aqueous solution was extracted with ether. The residue from ether fraction was isolated as nominated below. The glycoside was exposed to partial hydrolysis by treatment with $10 \%$ formic acid in cyclohexane and the resultant solution extracted with ethyl acetate. 


\section{Phytochemical screening of plant extract:-}

A small amount of the dry extract was used for the phytochemical tests (Harborne et.al.1994)for compounds which contain flavonoids, carbohydrates, glycosides, proteins and saponins.

\section{Anti-inflammatory activity by Carrageenan induced rat paw oedema:-}

The anti-inflammatory activity of the test compounds were calculated in albino rats employing the method (Diwan et.al.1989). Male albino rats (200 - $250 \mathrm{~g}$ ) of Wistar strain were secured from the College animal house. Animals were fasted overnight and were divided into control, standard and different test groups each consisting of six animals. The different test concentration at the dose of 100 and $200 \mathrm{mg} / \mathrm{kg}$ of isolated compounds, $300 \mathrm{mg}$ methanolic extracts and Diclofenac sodium (98\%, purchased from Sigma-Aldrich, India) at dose of $10 \mathrm{mg} / \mathrm{kg}$ were governed to the animals by oral route. Control group animals were received $1 \%$ DMSO at the dose of $10 \mathrm{~mL} / \mathrm{kg}$ body weight. They housed in cages and preserved under standard conditions at $26 \pm 2{ }^{\circ} \mathrm{C}$ and relative humidity 60 $65 \%$ and 12 hours light and 14 hours dark cycles each day for one week before and during the experiments. All animals were fed with the standard rodent pellet diet and water ad libitum. Before starting the experiment on animals, the experimental protocol was exposed to the scrutiny of the Institutional Animal Ethics Committee (IAEC), Bharathidasan University, Trichirappalli, Tamilnadu, India (Approval No. BDU/IAEC/2011/31/29.03.2011).

The acute inflammation was induced by the sub-plantar administration of $0.1 \mathrm{~mL}$ of $1 \%$ carrageenan in the right paw. Paw volume was measured by using digital plethysmometer (Ugo Basile-Italy) before administration of carrageenan and after 1, 2, 3, 4 and 5 hours intervals (Kouadio et.al.2000). The efficacy of different drug was verified on its ability to inhibit paw oedema as compared to control group.

Volume of edema $=$ Final Paw Volume - Initial Paw Volume

The Percentage inhibition of paw oedema was calculated by the formula as below.

$\%$ Inhibition of Paw oedema $=[(\mathrm{VC}-\mathrm{VT}) / \mathrm{VC}] \mathrm{x} 100$

Where, $\mathrm{VC}=$ Paw oedema of control group and VT = Paw oedema of treated group

\section{Acute toxicity studies:-}

Acute toxicity studies were carried out according to the literature (Ghosh, 2005). Animals were fasted for eighteen hours and used. A dose of $200 \mathrm{mg} / \mathrm{kg}$ of isolated compound and $300 \mathrm{mg} / \mathrm{kg}$ methanolic extracts of Cissus quadrangularis were administrated orally to 12 rats, additionally three rats were kept as control. The control group received distilled water. Then they were observed for 72 hours. Since no mortality was observed and the behavioral pattern was unaffected. No depth was observed at the end of the study.

\section{Statistical Analysis:-}

The experimental results were expressed as multiple comparisons of Mean \pm SEM were carried out by one way analysis of variance (ANOVA) followed by Dunnet Multiple Comparisons Test and statistical significance was defined as $\mathrm{P}<0.05$. 


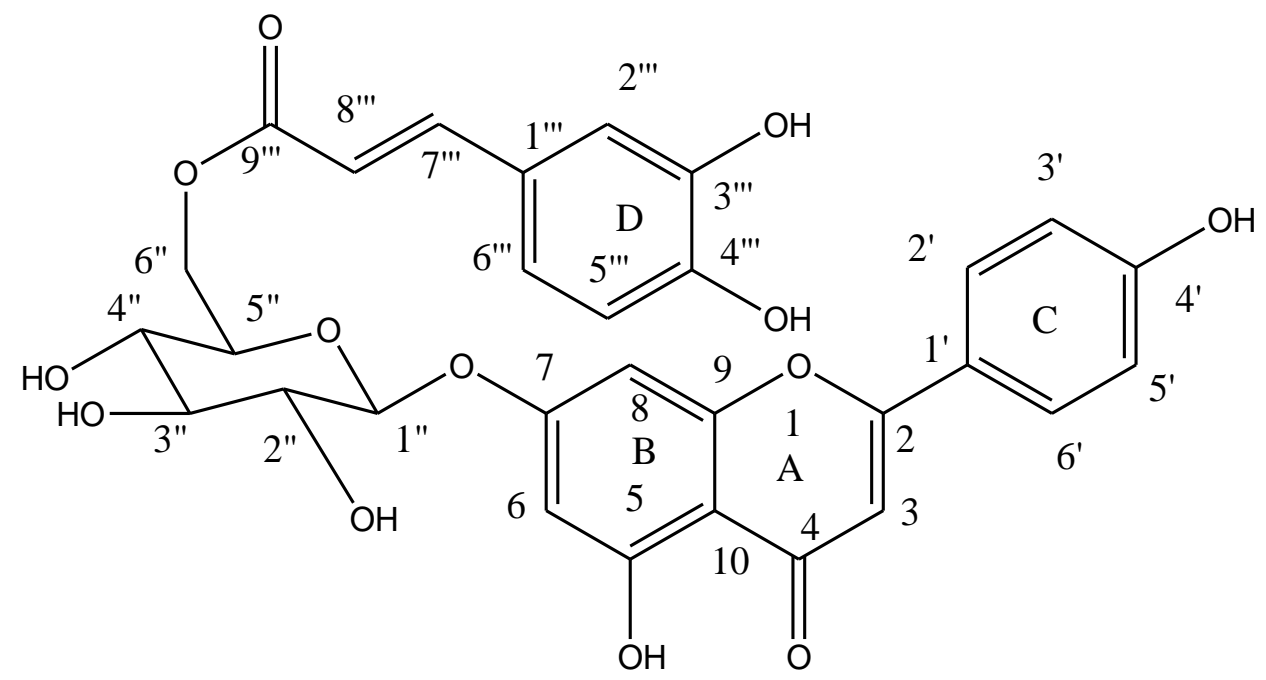

Figure 1: Structure of Apigenin - 7- O - (6" - O - caffeoyl) - $\beta$-D- glucopyranoside

Table 1:- Anti-inflammatory activity of apigenin-7-O-(6"-O-caffeoyl)- $\beta$-D-glucopyranoside extracted from Cissus quadrangularis

\begin{tabular}{|c|c|c|c|c|c|c|}
\hline \multirow{2}{*}{$\begin{array}{c}\text { S. } \\
\text { No. }\end{array}$} & \multirow[t]{2}{*}{ Treatment } & \multicolumn{5}{|c|}{ Anti-inflammatory activity $(\mathrm{cm})(\mathrm{M} \pm \mathrm{SD})$} \\
\hline & & $\mathbf{1 ~ h}$ & $2 \mathrm{~h}$ & $3 \mathbf{h}$ & $4 \mathrm{~h}$ & $5 \mathrm{~h}$ \\
\hline 1 & Normal Control & $2.14 \pm 0.08$ & $2.13 \pm 0.13$ & $2.11 \pm 0.14$ & $2.10 \pm 0.06$ & $2.10 \pm 0.04$ \\
\hline 2 & $\begin{array}{l}\text { Inflammatory Control (1\% } \\
\text { carragenan) }\end{array}$ & $3.84 \pm 0.05$ & $3.71 \pm 0.06$ & $3.68 \pm 0.02$ & $3.54 \pm 0.04$ & $3.53 \pm 0.02$ \\
\hline 3 & $\begin{array}{l}\text { Standard }(1 \% \text { carragenan }+ \\
\text { diclofenac sodium } 10 \mathrm{mg} / \mathrm{kg})\end{array}$ & $3.86 \pm 0.04$ & $3.43 \pm 0.08$ & $3.22 \pm 0.02$ & $2.91 \pm 0.03$ & $2.72 \pm 0.03$ \\
\hline 4 & $\begin{array}{l}1 \% \text { carragenan + apigenin } \\
\text { glycoside } \\
(100 \mathrm{mg} / \mathrm{kg})\end{array}$ & $3.85 \pm 0.04$ & $3.74 \pm 0.01$ & $3.65 \pm 0.01$ & $3.52 \pm 0.05$ & $3.48 \pm 0.01$ \\
\hline 5 & $\begin{array}{l}1 \% \text { carragenan + apigenin } \\
\text { glycoside } \\
(200 \mathrm{mg} / \mathrm{kg})\end{array}$ & $3.81 \pm 0.05$ & $3.70 \pm 0.06$ & $3.43 \pm 0.02$ & $3.15 \pm 0.04$ & $2.88 \pm 0.02$ \\
\hline 6 & $\begin{array}{l}1 \% \text { carragenan + methanol } \\
\text { extract } \\
(300 \mathrm{mg} / \mathrm{kg})\end{array}$ & $3.80 \pm 0.01$ & $3.71 \pm 0.11$ & $3.66 \pm 0.04$ & $3.54 \pm 0.08$ & $3.46 \pm 0.05$ \\
\hline
\end{tabular}

Data presented above are mean \pm standard deviation $(\mathrm{M} \pm \mathrm{SD})$ values of three replicates.

\section{Results and Discussion:-}

Chemical Constituents:-

The compound was obtained as a yellow amorphous powder (m.p: $240-242^{\circ} \mathrm{C}$ ), which gave a positive colour reactions for a hydroxyl flavone with several reagents (Kaneta et.al.1971). IR spectrum indicated the presence of hydroxyl stretching vibration at $3312 \mathrm{~cm}^{-1}$, the strong absorption band at $1646 \mathrm{~cm}^{-1}$ is due to carbonyl stretching vibration and the aromatic ring $\left(1559,1537 \mathrm{~cm}^{-1}\right)$, meanwhile strong absorption at 272 and $319 \mathrm{~nm}$ was observed in UV spectrum (Silverstein, 1998). HPLC analysis showed the presence of a flavone glycoside. The identified peak with the retention time of $26.4 \mathrm{~min}$. The ${ }^{1} \mathrm{H}$ NMR spectrum indicated the presence of two meta coupled aromatic doublets at $\delta 7.92$ and $7.91 \mathrm{ppm}$ corresponds to $\mathrm{H}-6$ and $\mathrm{H}-8$ protons. There are four $-\mathrm{OH}$ groups in the molecule among this $-\mathrm{OH}$ groups present in ring $\mathrm{B}$ and $\mathrm{C}$ appeared at $\delta 12.4 \mathrm{ppm}$. The remaining two $-\mathrm{OH}$ groups present in ring D appeared at $\delta 10.1 \mathrm{ppm}$. The $-\mathrm{OH}$ groups of the ring $\mathrm{B}$ and $\mathrm{C}$ appeared at higher chemical shift value $(\delta 12.4$ $\mathrm{ppm})$, then the $-\mathrm{OH}$ group present $\mathrm{D}$ - ring which is due to hydrogen bond formation between carbonyl group and $\mathrm{OH}$ group present in fifth carbon of the B - ring. Additionally one singlet signal exhibited at $\delta 8.83 \mathrm{ppm}$ which has assigned to $\mathrm{H}-3$ of isoflavone. However, additional resonances ascending from a D-glucose unit with characteristic signals at $\delta 5.13 \mathrm{ppm}$ for anomeric proton and the rest of the sugar protons seem between $\delta 3.36-4.07 \mathrm{ppm}(\mathrm{m}$, unresolved, pyranose protons) (Fairouz et.al.2010). ${ }^{13} \mathrm{C}-\mathrm{NMR}$ signal appear at $\delta 198.4 \mathrm{ppm}$ shows that $>\mathrm{C}=\mathrm{O}$ at C-4. 
The sugar carbon signals exposed at $\delta 105.9,77.3,76.7,72.6,61.8$ and $53.7 \mathrm{ppm}$ are similar with those reported for $O$ - glucoside ( $\mathrm{Li}$ et.al. 2003). The ${ }^{1} \mathrm{H}$ NMR spectrum shown the presence of anomeric proton signal at $\delta 5.13 \mathrm{ppm}$ indicated the presence of $O$ - linked sugar. It has recognized that the sugar moiety bonded to hydroxyl group at C-7 of the aglycone as assumed from the correlation between the anomeric proton at $\delta 5.13 \mathrm{ppm}$ and the C-7 at $\delta 147.3$ ppm (Kumar et.al.2003). These aromatic protons of D - ring appeared in between $\delta 7.26-7.43 \mathrm{ppm}$ and further these are confirmed by the appearance of respective carbon signals between $\delta 124.4-147.3 \mathrm{ppm}$. The ${ }^{1} \mathrm{H}-\mathrm{NMR}$ spectrum also revealed two doublets, each for $1 \mathrm{H}$, at $\delta 7.29\left(\mathrm{H}-7^{\prime \prime \prime}\right)$ and $7.28\left(\mathrm{H}-8^{\prime \prime \prime}\right)$. The large value of coupling constant showed the presence of trans-disubstituted ethylene moiety in the molecule. The ${ }^{1} \mathrm{H}$ and ${ }^{13} \mathrm{C}$ chemical shifts of olefinic protons and carbons $\left[\delta 116.8\left(\mathrm{C}-7^{\prime \prime \prime}\right)\right.$ and $\left.112.5\left(\mathrm{C}-8^{\prime \prime \prime}\right)\right]$ were comparable to those of trans-cinnamic acid (Pouchert, 1974). The ${ }^{13} \mathrm{C}$ chemical shifts of a carbon at $\delta 176.1$ showed the presence of carboxylic functional group in the molecule. The ${ }^{13} \mathrm{C}$ chemical shifts of carbon atoms at $\delta 128.1\left(\mathrm{C}-3^{\prime \prime \prime}\right), 126.6\left(\mathrm{C}-4^{\prime \prime \prime}\right)$, indicated that the hydroxyl group are attached at C-3"' and C-4"' positions. The position of ethylene function was determined by chemical shift of C-1"' carbon at $\delta 128.5$ and the downfield chemical shifts of C-7"' carbon and H-7"' proton of ethylene moiety. Based on their RT values, UV, IR, ${ }^{1} \mathrm{H}-\mathrm{NMR}$ and ${ }^{13} \mathrm{C}-\mathrm{NMR}$ data's, the flavone glycoside obtained from ethyl acetate fraction of the flower from Cissus quadrangularis could be confirmed as Apigenin - 7- O - (6" O - caffeoyl) - $\beta$-D- glucopyranoside (Figure 1).

\section{Anti-inflammatory Activity:-}

Inhibition of carrageenan convinced inflammation in rats is one of the most suitable test procedures to screen antiinflammatory agents. The paw oedema convinced by carrageenan involves several chemical mediators such as histamine, serotonin, bradykinin and prostaglandins (Vinegar et.al.1987). The intraperitoneal injection of the carrageenan produced an inflammatory oedema which increased gradually, reaching its maximum at the $5^{\text {th }}$ hour after injection. In this study, the isolated compound apigenin - 7- O - (6" - O - caffeoyl) - $\beta$-D- glucopyranoside tested at doses of 100 and $200 \mathrm{mg} / \mathrm{kg}$ showed substantial anti-inflammatory activity in carrageenan induced rat paw oedema model (Table 1). Diclofenac Sodium is a reference drug, a potent non-steroidal anti-inflammatory which acts by constraining cyclo-oxygenage. It presented significant inhibitory effects were observed started at first hour after carrageenan administration. The compound apigenin - 7- O - (6" - O - caffeoyl) - $\beta$-D- glucopyranoside at the dose of $200 \mathrm{mg} / \mathrm{kg}$ had the highest percentage inhibition of the paw volume (3.15 \pm 0.04$)$ and at the dose of $100 \mathrm{mg} /$ $\mathrm{kg}$ produced $(3.52 \pm 0.05)$ inhibition of the paw volume at 4 hours a performance well similar with the standard drug Diclofenac Sodium (2.91 \pm 0.03$)$. Also after the administration of carrageenan with the methanol extract of Cissus quadrangularis at the dose of $300 \mathrm{mg} / \mathrm{kg}$ exerted considerable inhibitory effect on paw oedema in rats starting from the first hour. The maximum inhibition $(3.46 \pm 0.05)$ elicited by the methanol extract was recorded at 5 hours. In the carrageenan-induced rat paw oedema model, apigenin - 7- O - (6" - O - caffeoyl) - $\beta$-D- glucopyranoside indicated significant inhibitory effect on the oedema formation.

\section{Conclusion:-}

The isolation of active compounds is significant to propose medicinal plant Cissus quadrangularis as another approach to resistance management and substantial inhibitory effect on the oedema formation. The compound apigenin - 7- O - (6" - O - caffeoyl) - $\beta$-D- glucopyranoside isolated from Cissus quadrangularis flowers at the dose of $200 \mathrm{mg} / \mathrm{kg}$ had the highest percentage inhibition of the paw volume.

\section{Conflict Of Interest:-}

The authors declare no conflict of interest. 


\section{References:-}

1. Anonymous. (1992), Indian Medicinal Plants, Vol. 2, Orient Longman Ltd., 112.

2. Diwan,P.V., Karwande,I., Margaret,I., Sattur,P.B.(1989), Indian Journal of Pharmacology,21, 1-7.

3. Duncan,B.B., Schmidt,M.I., Pankow,J.S., Ballantyne,C.M., Couper,D., Vigo,A., Hoogeveen,R., Olsom,A.R., Heiss, G. (2003),Diabetes, , 52: 1799-1805.

4. Fairouz,M., Amar,Z., Narimane,S., Ahmed,T., Salah,R. (2010), Rec. Nat. Prod., 4, 91-95.

5. Ghosh,M.N.(2005), Fundamentals of Experimental Pharmacology, $3^{\text {rd }}$ edition, Hilton and Company, Kolkatta, 190-197.

6. Guhabakshi,D.D., Pal,D.C., Sersuma,P. (2001), A Lexicon of Medicinal Plants in India, Vol. 1, NayaProkash, 443-45.

7. Harborne,J.B., Williams,C.A.(2000), Phytochemistry,55, 481-504.

8. Harborne,J.B.(1994), Flavone and flavone glycosides, InThe flavonoids: Advances in Research since 1986, Chapman \& Hall, Cambridge, UK, 337-385.

9. Harborne,J.B.(1994), The Flavonoids, Advances in Research,Chapmann\& Hall, London.

10. Jainu,M., Devi,C.S.(2003), Journal of Clinical Biochemical Nutrition, 34, 43-47.

11. Kaneta,M.(1971), Fukushima Tech. Jr. Col. Bull., 7,40-44.

12. Kouadio,F., Kanko,C., Juge,M., Grimaud,N., Jean,A., Guessan,Y.T., Petit,J.Y. (2000), Phytotherapy Research,14, 635-637.

13. Kumar Roy,M., Nakahara,K., Nathalang,V., Trakoontivakorn,G., Takenaka,M., Isobe,S.,Tsushidat, T.(2007), Pharmazie, 62, 149-153.

14. Li,R.M., Myers,S.P., Leach,D.N., Lin,G.D., Leach,G.(2003), J. Ethnopharmacol., 85, 25-32.

15. Pouchert,C.J., Compbell,J.R.(1974), The Library of NMR Spectra, Vol. 4, Aldrich Chemical Co., Milwaukee, 144.

16. Schmid-Schönbein,G.W.(2006), Annu. Rev. Biomed. Eng., 8, 93-151.

17. Silverstein,R.M., Webster,F.X.(1998), Spectrometric identification of organic compounds, $6^{\text {th }}$ edn., John Wiley, New York.

18. Vvedenskaya,I.O., Vorsa,N. (2004), Plant Sci., 167, 1043-1054.

19. Vinegar,R., Truax,FJ. Selph,J.L., Johnston,P.R., Venable,A.L., McKenzie,K.K.(1987), Federation Proceedings, 46, 118-126.

20. Weiss,U.(2008), Nature, 454, 427. 